\title{
THE EARLY DETECTION OF PYREXIA IN THE NEWBORN
}

\author{
BY \\ W. S. CRAIG \\ From the Department of Paediatrics and Child Health, University of Leeds
}

(RECEIVED FOR PUBLICATION AUGUST 31, 1962)

'It has . . . become customary to take the body temperature of the newborn only if fever or chilling is suspected.'

\section{H. N. Sanford and C. G. Grulee}

References in the literature to the occurrence of fever in specified neonatal conditions are almost invariably qualified by the reservation that pyrexia is not a constant finding. This applies alike to infections and to traumatic conditions. Moreover, there is uncertainty concerning 'inanition fever'. In one well-known textbook this type of fever is given as the most frequent form of pyrexia, although elsewhəre in the same chapter the statement is made that 'it is very doubtful if inanition fever . . . actually exists' (Sanford and Grulee, 1961a). The present paper describes the circumstances in which fever due to other than environmental causes was recorded after the first $\mathbf{2 4}$ hours of life in $\mathbf{3 5 8}$ infants.

\section{Clinical Material}

All infants in the study were under clinical observation in the Leeds Maternity Hospital. Two series of infants are included. The first (Series A) consists of a control group of 282 unselected babies who were nursed for a period of not less than 10 days in the same lying-in ward and in whom, while in hospital, no signs of disturbed health were detected. There were 10 additional babies in Series $A$ in whom signs of disturbed health did develop unexpectedly. Details are given later. The second series (Series B) is composed of those infants (358) who developed a temperature in excess of $99.4^{\circ} \mathrm{F}$. $\left(37.4^{\circ} \mathrm{C}\right.$.) on more than one occasion, while in the special baby care unit of the hospital. Only babies in open cots and without hoi-water bottles or electric blankets were included in the two series. Admission of babies in the control Series A took place during a 12-month period commencing April 1, 1961, and of those in the major series during the period January 1, 1953, to December 31,1961 .

All 292 babies in Series A were born in hospital. There were 143 males and 149 females, and 151 were live-born first babies. Of the 358 infants in
Series B, 263 were born in Leeds Maternity Hospital, 73 in their own homes, 17 in nursing homes and 5 in other maternity hospitals. Males numbered 216 and females 142, and there were 178 live-born first infants. The estimated gestation periods, birth weights and methods of delivery of the two series are compared in Table 1.

TABLE 1

SERIES A AND B: GESTATION PERIODS. BIRTH WEIGHTS AND METHODS OF DELIVERY COMPARED

\begin{tabular}{|c|c|c|c|c|c|c|}
\hline \multirow{3}{*}{ Feature } & & & \multicolumn{4}{|c|}{ Series } \\
\hline & & & \multicolumn{2}{|c|}{$\mathbf{A}$} & \multicolumn{2}{|c|}{ B } \\
\hline & & & No. & $\%$ & No. & $\because$ \\
\hline $\begin{array}{c}\text { Gestation Period: } \\
<38 \text { weeks } . . \\
38-42 \text { weeks } \\
>42 \text { weeks } . .\end{array}$ & $\begin{array}{l}\cdots \\
\cdots \\
\cdots\end{array}$ & $\begin{array}{l}\cdots \\
\cdots \\
\cdots\end{array}$ & $\begin{array}{r}18 \\
261 \\
13\end{array}$ & $\begin{array}{r}6 \\
89 \\
5\end{array}$ & $\begin{array}{r}77 \\
254 \\
27\end{array}$ & $\begin{array}{r}21 \\
71 \\
8\end{array}$ \\
\hline $\begin{array}{l}\text { Birth Weight: } \\
>51 \text { lb. }(2.500 \mathrm{gg}) \\
>51 \text { lb. }(2.500 \mathrm{~g} .)\end{array}$ & $\begin{array}{l} \\
\cdots\end{array}$ & $\begin{array}{l}\cdots \\
\cdots\end{array}$ & $\begin{array}{r}18 \\
274\end{array}$ & $\begin{array}{r}6 \\
94\end{array}$ & $\begin{array}{r}81 \\
277\end{array}$ & 23 \\
\hline $\begin{array}{l}\text { Delivery: } \\
\text { Normal } \\
\text { Instrumental } \\
\text { Operative . . }\end{array}$ & $\begin{array}{l}\cdots \\
\ldots\end{array}$ & $\begin{array}{l}\cdots \\
\cdots \\
\cdots\end{array}$ & $\begin{array}{r}220 \\
48 \\
24\end{array}$ & $\begin{array}{r}75 \\
16 \\
9\end{array}$ & $\begin{array}{r}238 \\
72 \\
48\end{array}$ & $\begin{array}{l}67 \\
20 \\
13\end{array}$ \\
\hline
\end{tabular}

\section{Method of Temperature Recording}

Rectal temperatures were recorded before feeds four-hourly in Series A and three-hourly in Series B, the number of staff available determining the routine employed. One-minute clinical thermometers were used, being inserted to a depth of not less than $5 \mathrm{~cm}$. beyond the anal sphincter and retained in position for at least two minutes. Readings were commenced after the first day of life and recordings were made immediately after reading the thermometer.

\section{Clinical Findings}

Series A: Control Group (292 Infants). In 282 


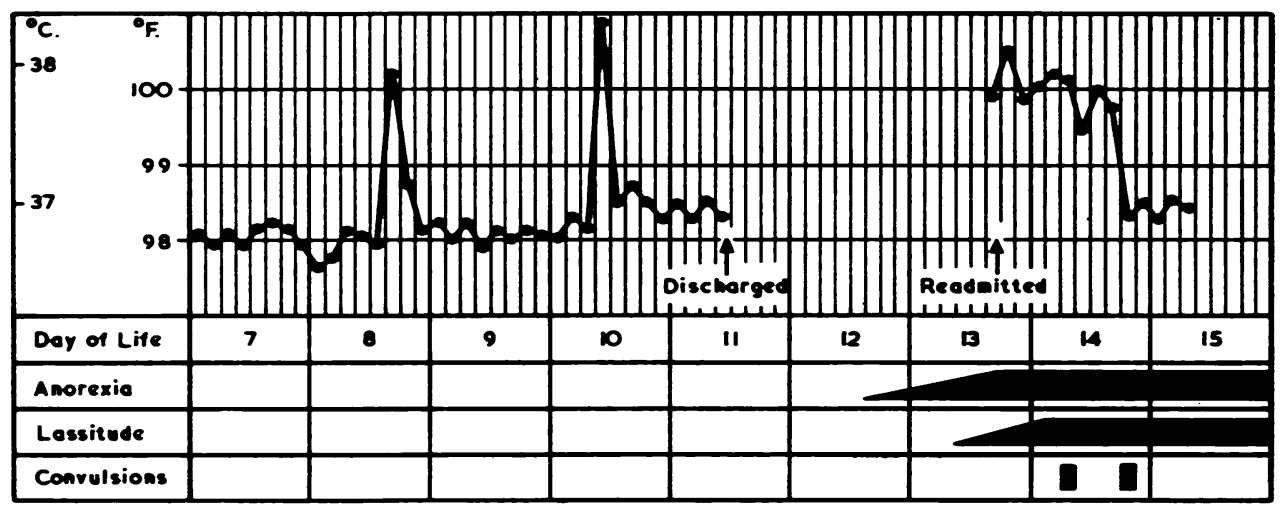

FK. 1.-Pyrexia in association with septicaemia and meningitis. Two isolated increases in temperature in the 72 hours preceding discharge: readmitted with $E$. coli septicaemia 48 hours after discharge.

infants fluctuations in rectal temperature after the first day of life did not at any time fall below $97^{\circ} \mathrm{F}$. $\left(36 \cdot 1^{*}\right.$ C. $)$ or exceed $99^{\circ}$ F. $\left(37 \cdot 2^{\circ}\right.$ C. $)$. There were 10 exceptions to this general finding. Isolated rises in temperature to $99 \cdot 6^{\circ} \mathrm{F} .\left(37 \cdot 5^{\circ} \mathrm{C}.\right), 99 \cdot 8^{\circ} \mathrm{F}$. $\left(37 \cdot 7^{\circ}\right.$ C.) and $100 \cdot 2^{\circ}$ F. $\left(37 \cdot 8^{\circ}\right.$ C. $)$ occurred in two, three and two babies respectively in the first week of life, and were shown in each case to be due to temporary inadequacy of fluids. Fever ranging from $99 \cdot 8^{\circ}$ to $101 \cdot 6^{\circ}$ F. $\left(37 \cdot 7^{\circ}-38 \cdot 7^{\circ}\right.$ C. $)$ was recorded on one or two occasions between the tenth and fourteenth day in three other babies, each of whom developed clinical evidence of infection within 36 hours of discharge home (Fig. 1).
Series B: (358 Infants). The findings are summarized in Table 2 in which variations in the type of temperature are presented in relation to the clinical events contributing to the occurrence of pyrexia. Infection, stress arising from labour and/or delivery, dehydration and retention of the products of haemorrhage were, in that order of frequency, the clinical features found most commonly in association with fever. One or more of these clinical features was present in $302(84 \%)$ of the infants in Series B. Table 3 gives details of the various forms of infections according as they were deep or superficial; and Table 4 summarizes the findings associated with perinatal stress. The

TAB $\vec{E} 2$

CHARACTERISTICS OF TEMPERATURE IN RELATWWN

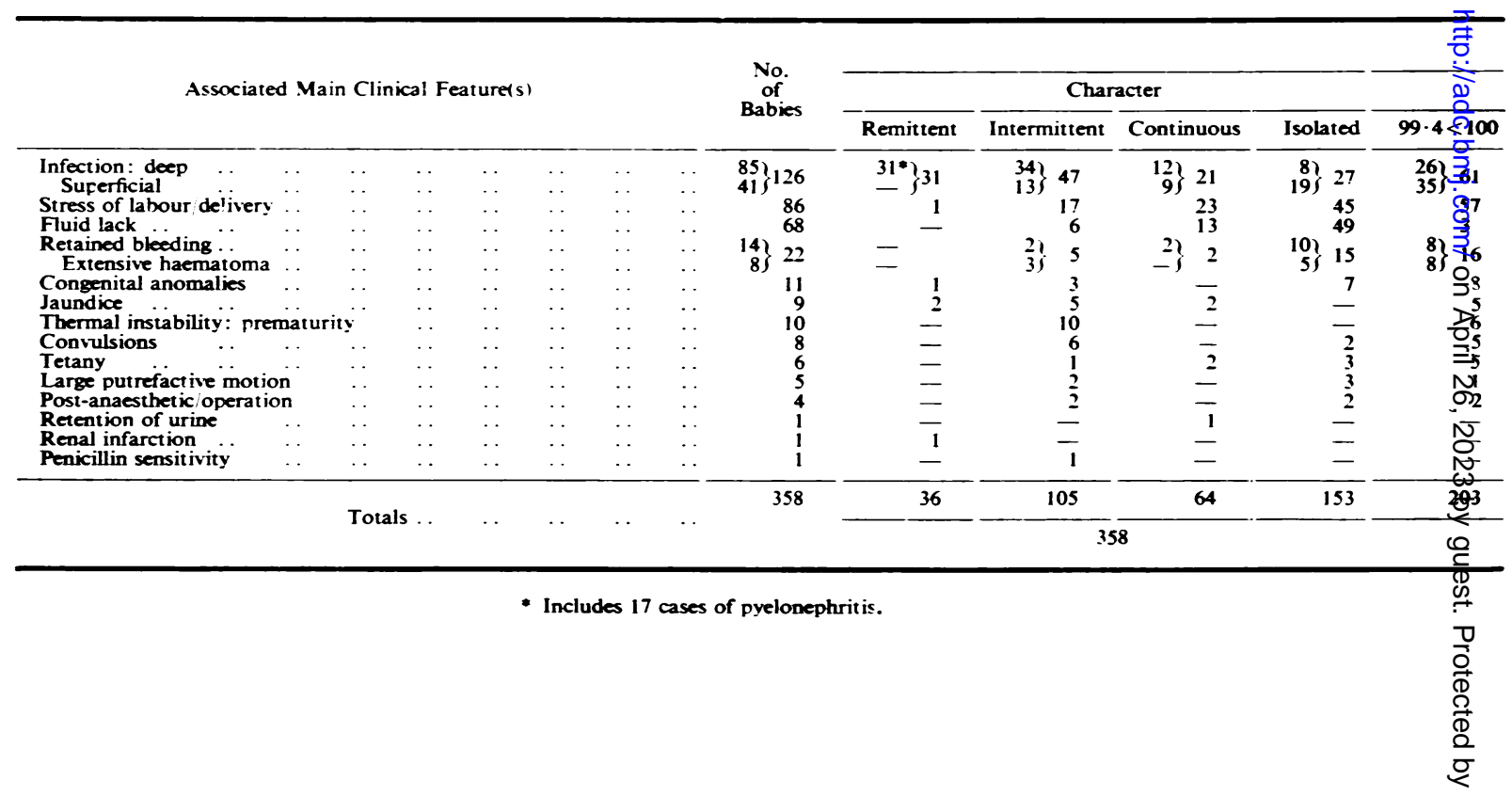


TABLE 3

PYREXIA ASSOCIATED WITH INFECTIONS (126 INFANTS)

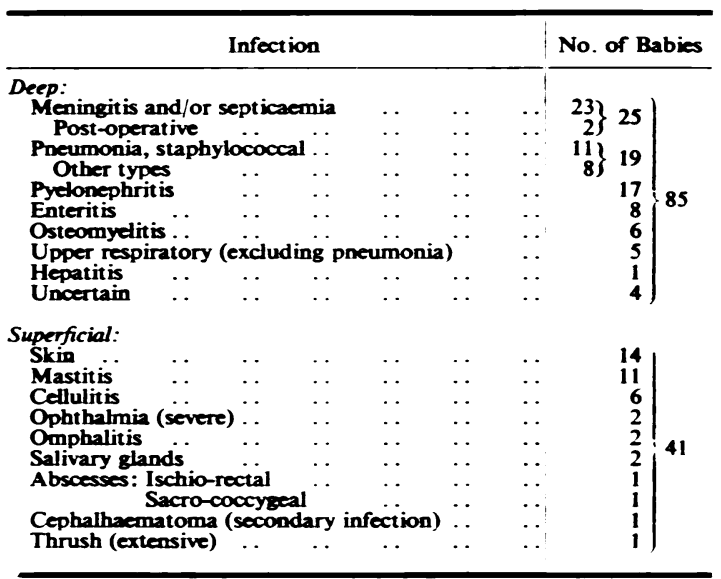

circumstances giving rise to dehydration whether as a result of inadequate fluid intake or excessive fluid loss are summarized in Table 5, and Table 6 indicates the clinical conditions in which the products of haemorrhage were retained.

Temperature Variations. The age of onset varied from 24 hours to over 14 days after birth. Stress of birth was the condition most commonly associated with pyrexia appearing on the second or third day of life, and infection was the most common association with fever first developing during or after the first half of the second week of life.
TABLE 4

PYREXIA FOLLOWING STRESS OF DELIVERY AND/OR BIRTH (86 INFANTS)

\begin{tabular}{|c|c|c|c|c|c|c|}
\hline \multicolumn{5}{|c|}{ Clinical Features } & \multicolumn{2}{|c|}{ No. of Babies } \\
\hline $\begin{array}{l}\text { Foetal distress and asphyxia } \\
\text { Foetal distress and asphyxia }\end{array}$ & & nivulsio & & $\cdots$ & 20) 29 & \\
\hline $\begin{array}{l}\text { Asphyxia } \\
\text { Asphyxia and convulsions }\end{array}$ & $\begin{array}{l}\cdots \\
\cdots\end{array}$ & $\cdots$ & $\begin{array}{l}\cdots \\
\cdots\end{array}$ & $\cdots$ & $\left.\begin{array}{r}16 \\
5\end{array}\right\} 21$ & \\
\hline $\begin{array}{l}\text { Intracranial disturbance* } \\
\text { Intracranial disturbance and }\end{array}$ & conv & sions & $\begin{array}{l}\cdots \\
\cdots\end{array}$ & $\begin{array}{l}\cdots \\
\cdots\end{array}$ & 20) 26 & \\
\hline $\begin{array}{l}\text { Intracranial haemorrhage } \\
\text { Intractanial haemorrhage ar }\end{array}$ & & isions & $\begin{array}{l}\cdots \\
\cdots\end{array}$ & $\begin{array}{l}\cdots \\
\ldots\end{array}$ & $\left.\begin{array}{l}8 \\
2\end{array}\right\} 10$ & \\
\hline
\end{tabular}

- Neuromuscular irritability following difficult delivery or birth irrespective of whether signs of asphyxia were present.

-

The maximum elevation of temperature in 203 babies $(57 \%)$ did not exceed $100^{\circ} \mathrm{F} .\left(37 \cdot 8^{\circ} \mathrm{C}\right.$.), and of the remainder $93(26 \%), 45(12 \%)$ and $17(5 \%)$ infants had temperatures between $100^{\circ}$ and $102^{\circ} \mathrm{F}$. $\left(37 \cdot 8^{\circ}-38 \cdot 9^{\circ}\right.$ C.), between $102^{\circ}$ and $104^{\circ}$ F. (38. $40^{\circ}$ C. $)$ and over $104^{\circ}$ F. $\left(40^{\circ}\right.$ C. $)$ respectively. Infection was the commonest cause of, and together with dehydration accounted for over $75 \%$ of pyrexias in excess of $102^{\circ} \mathrm{F}$. $\left(38 \cdot 9^{\circ} \mathrm{C}\right.$.).

The duration of fever in 108 infants $(31 \%)$ was less than 24 hours, and was present for two or three days in approximately the same number of cases. Seventy-one $(20 \%), 29(8 \%)$ and $33(9 \%)$ babies had fever for four to seven days, seven to 14 days and for longer than two weeks respectively. Of babies with fever persisting for more than four days, $58 \%$ had an infection.

Temperature differences varied in character. The

TO PROBABLE UNDERLYING CAUSE (358 INFANTS)

\begin{tabular}{|c|c|c|c|c|c|c|c|c|c|c|c|c|}
\hline \multicolumn{13}{|c|}{ Ternperature } \\
\hline \multicolumn{2}{|c|}{ Maximum ( ${ }^{\circ} \mathrm{F}$.) } & \multirow[b]{2}{*}{104 and $>$} & \multicolumn{4}{|c|}{ Onset (days) } & \multicolumn{6}{|c|}{ Duration (days) } \\
\hline $100<102$ & $102<104$ & & $2-3$ & $4-7$ & $8-13$ & 14 and $>$ & $>1$ & 2 & 3 & 4-7 & $7-14$ & $>14$ \\
\hline $\left.\begin{array}{r}24 \\
6\end{array}\right\} 30$ & 24) 24 & 11) 11 & $\left.\begin{array}{r}14 \\
3\end{array}\right\} 17$ & $\begin{array}{l}17 \\
16\end{array} 33$ & $\left.\begin{array}{l}41 \\
20\end{array}\right\} 61$ & $\left.\begin{array}{r}13 \\
2\end{array}\right\} 15$ & $\left.\begin{array}{l}6 \\
6\end{array}\right\} 12$ & $\left.\begin{array}{c}10 \\
8\end{array}\right\} 18$ & $\left.\begin{array}{c}10 \\
9\end{array}\right\} 19$ & $\left.\begin{array}{l}29 \\
12\end{array}\right\} 41$ & $\left.\frac{12}{3}\right\} 15$ & $\left.\begin{array}{c}18 \\
3\end{array}\right\} 21$ \\
\hline $\begin{array}{l}25 \\
19\end{array}$ & $\begin{array}{l}4 \\
9\end{array}$ & $-\frac{1}{3}$ & $\begin{array}{l}65 \\
20\end{array}$ & $\begin{array}{l}16 \\
25\end{array}$ & 25 & $\frac{-}{3}$ & $\begin{array}{l}28 \\
42\end{array}$ & $\begin{array}{r}24 \\
5\end{array}$ & $\begin{array}{r}14 \\
6\end{array}$ & $\begin{array}{r}12 \\
9\end{array}$ & $\begin{array}{l}6 \\
3\end{array}$ & 2 \\
\hline 2$\} 2$ & 3) 3 & $1\}$ & $\begin{array}{l}9 \\
6\end{array} 15$ & 5) 7 & - & E & 4) 4 & $\left.\begin{array}{l}6 \\
3\end{array}\right\} 9$ & $\left.\begin{array}{l}4 \\
1\end{array}\right\} 5$ & $-2\} \quad 2$ & $\overrightarrow{2}\}$ & - \\
\hline 1 & 2 & $\overline{3}$ & 9 & $\frac{2}{6}$ & $-\frac{1}{2}$ & 二 & $\begin{array}{r}6 \\
3\end{array}$ & 3 & - & 2 & -7 & 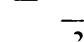 \\
\hline$\frac{2}{4}$ & 二 & $\underline{2}$ & 1 & $\begin{array}{l}6 \\
5\end{array}$ & $\begin{array}{l}2 \\
5\end{array}$ & 二 & -3 & $\frac{1}{2}$ & $\overline{3}$ & $\frac{2}{2}$ & $\frac{1}{2}$ & $\frac{2}{1}$ \\
\hline 2 & 1 & - & 2 & 2 & - & 4 & 2 & $\overline{1}$ & - & 1 & 二 & 4 \\
\hline 3 & $\overline{1}$ & 二 & $\begin{array}{l}6 \\
5\end{array}$ & 二 & 二 & 二 & $\begin{array}{l}5 \\
5\end{array}$ & 1 & 二 & 二 & 二 & Z \\
\hline 2 & - & - & 2 & 2 & - & - & 1 & 3 & - & - & - & - \\
\hline 1 & 7 & - & 1 & $T$ & - & 二 & - & 1 & 7 & - & 二 & - \\
\hline 1 & - & - & $\overline{1}$ & - & - & 二 & 二 & $\overline{1}$ & $\underline{-}$ & 二 & 二 & 二 \\
\hline 93 & 45 & 17 & 144 & 99 & $\$ 3$ & 22 & 108 & 69 & 48 & 71 & 29 & 33 \\
\hline \multicolumn{2}{|c|}{358} & & \multicolumn{4}{|c|}{358} & \multicolumn{6}{|c|}{358} \\
\hline
\end{tabular}




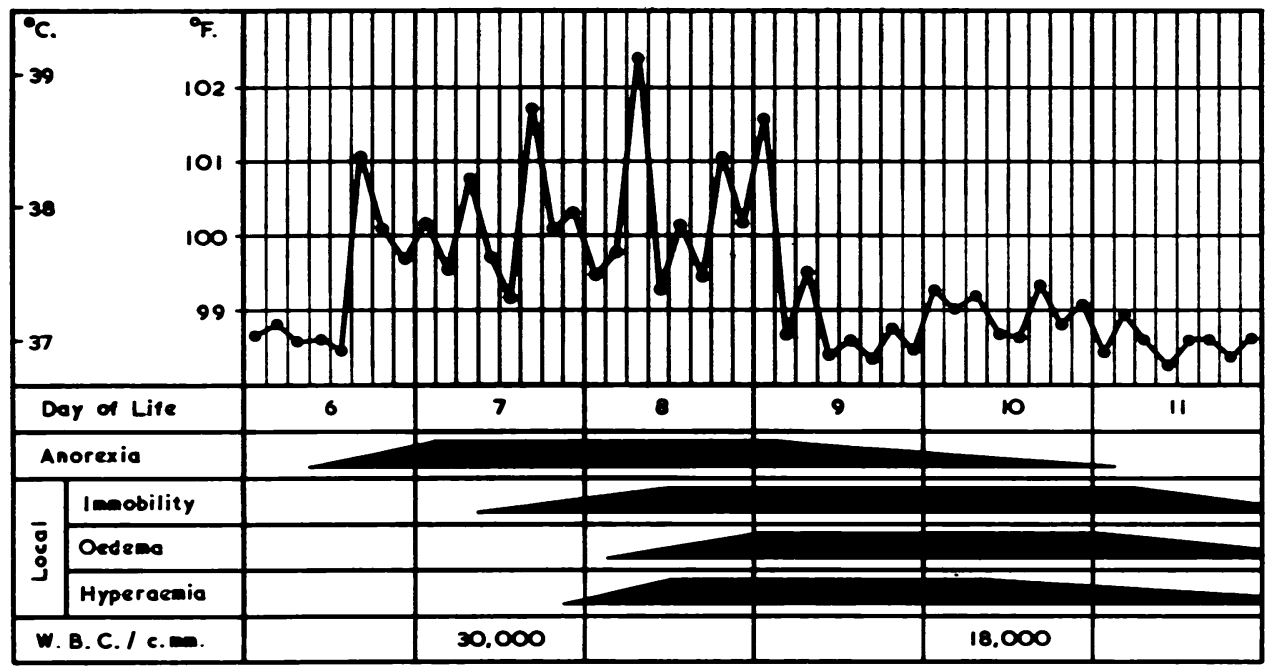

FK. 2.-Pyrexia in association with osteomyelitis (Staphylococcus aureus).

occurrence of isolated elevations was the commonest finding, being noted in 153 babies $(42 \%)$. Intermittent fever was present in $105(29 \%)$ and continuous fever in $64(19 \%)$ infants. There were $36(10 \%)$ examples of remittent pyrexia. Either infection or stress of birth was a feature of $64 \%$ of the cases with continuous fever and $51 \%$ of those with intermittent fever. Infection accounted for 31 of 36 examples of remittent pyrexia, and of the 31 cases 17 were suffering from pyelonephritis.

Temperature in Relation to Contributory Causes. Of the 358 infants in Series B, infection (Table 3) was a feature of $126(35 \%)$. The first appearance of pyrexia was delayed until the fourth day or later in 109 of these 126 babies. and occurred in the second week of life in 61 infants. Maximum temperatures in excess of $100^{\circ} \mathrm{F} .\left(37 \cdot 8^{\circ} \mathrm{C}\right.$. $)$ were as common as those under $100=\mathrm{F}$., and fevers persisting for more than four days were commoner than those lasting for a shorter period. Fever was usually continuous, intermittent or remittent and consisted of isolated elevations of temperature in only 27 infants, in 19 of whom the infection was superficial.

In general, deep infections were associated with temperatures of later onset, greater severity and longer duration than superficial infections, but the extent to which the trend was influenced by antibiotic therapy is uncertain. Three forms of deep infection invariably associated with high and irregular fever were staphylococcal osteomyelitis (Fig. 2), staphylococcal pneumonia and pyelonephritis regardless of the type of infecting organism. Of particular interest was the finding that severe febrile reactions associated with generalized coliform infection appeared to be limited to those cases in which infection had involved the meninges or kidneys.

The incidence of fever in superficial infections was significantly less than in deep infection. Fever was frequently absent in the presence of infections of the skin, nail beds, eyes and nasal orifices, but was a feature of almost every case of purulent mastitis and cellulitis. Surprisingly, pyrexia was not a constant accompaniment of severe infection of the salivary glands. This may be partially explained by the fact that there was spontaneous drainage of purulent material into the buccal cavities of infants who were apyrexial.

Stress of labour and or delivery (Table 4 and Fig. 3) was a feature of $86(24 \%)$ babies in the total series of 358 . In the great majority of instances fever developed within 36 to 72 hours of birth. Temperatures in excess of $102^{\circ}$ F. $\left(38^{\circ} 9^{-}\right.$C. $)$were exceptional and took the form of transient isolated elevations as frequently as of continuous or remittent type. The temperature usually subsided within one to three days, but occasionally persisted longer in the presence of continuing pronounced restlessness or of convulsions slow to respond to sedation. Infants listed against stress of labour in Table 2 were in receipt of fluids in amounts appropriate to their weight and age and did not show signs of inanition. 
Dehydration (Table 5 and Fig. 4) was the third most common finding associated with pyrexia. Clinical features common to all babies in the dehydration group included varying degrees of restlessness, thirst, and dryness of the skin and mucous membranes. Depending upon the contributory cause, dehydration fever developed at any time in the first fortnight and characteristically was of short duration, responding rapidly to the administration of increased fluids. Temperatures under $100^{\circ}$ F. $\left(37 \cdot 8^{\circ}\right.$ C. $)$ were more common than those above that level; and temperatures in excess of $102^{\circ} \mathrm{F} .\left(38^{\circ} 9^{\circ} \mathrm{C}\right.$.) were recorded in only 12 babies. Exceptions to these generalizations were explained by difficulty in quickly offsetting the functional disturbance arising from such conditions as hiatus hernia and Hirschsprung's disease.

Where retained blood (Table 6 and Fig. 5) was responsible for the pyrexia, the time of onset of fever was usually some 24 to 36 hours after the occurrence of haemorrhage. This applied to blood retained in the alimentary tract irrespective of whether the source of blood was intrinsic or maternal. It applied also to extensive interstitial extravasation of blood, whether due to trauma during delivery or to postnatal haemorrhage attributable to a coagulation defect of the blood. Fever did not usually exceed $100^{\circ}$ F. $\left(37 \cdot 8^{\circ}\right.$ C. $)$, but was higher when there was bleeding into serous cavities and in the presence of the massive intestinal haemorrhage of duodenal ulceration. Temperatures associated with extensive haematomata were low but persisted rather longer than the slightly
TABLE 5

PYREXIA CONTRIBUTED TO BY LACK OF FLLID (68 BABIES)

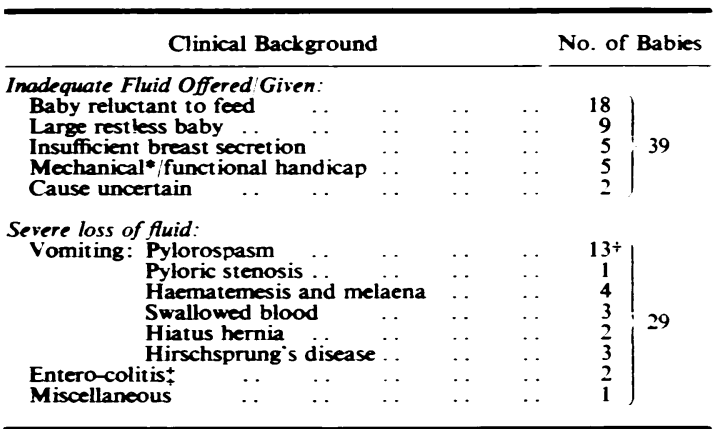

- Cleft palate, micrognathia, epulis, etc.

+ Nine of these cases occurred before early gastric lavage was employed in routine management.

¥ Negative bacteriological and virological cultures.

TABLE 6

PYREXIA ASSOCIATED WITH RETAINED BLEEDING (22 INFANTS)

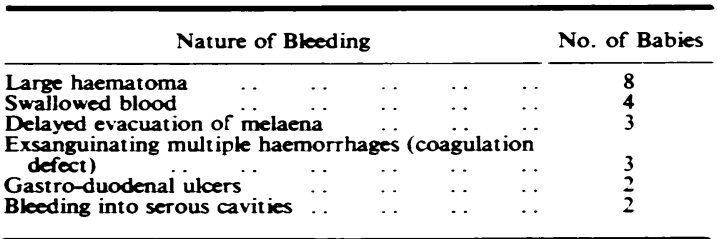

higher temperatures found in babies in whom there was prolonged retention of blood in the intestine.

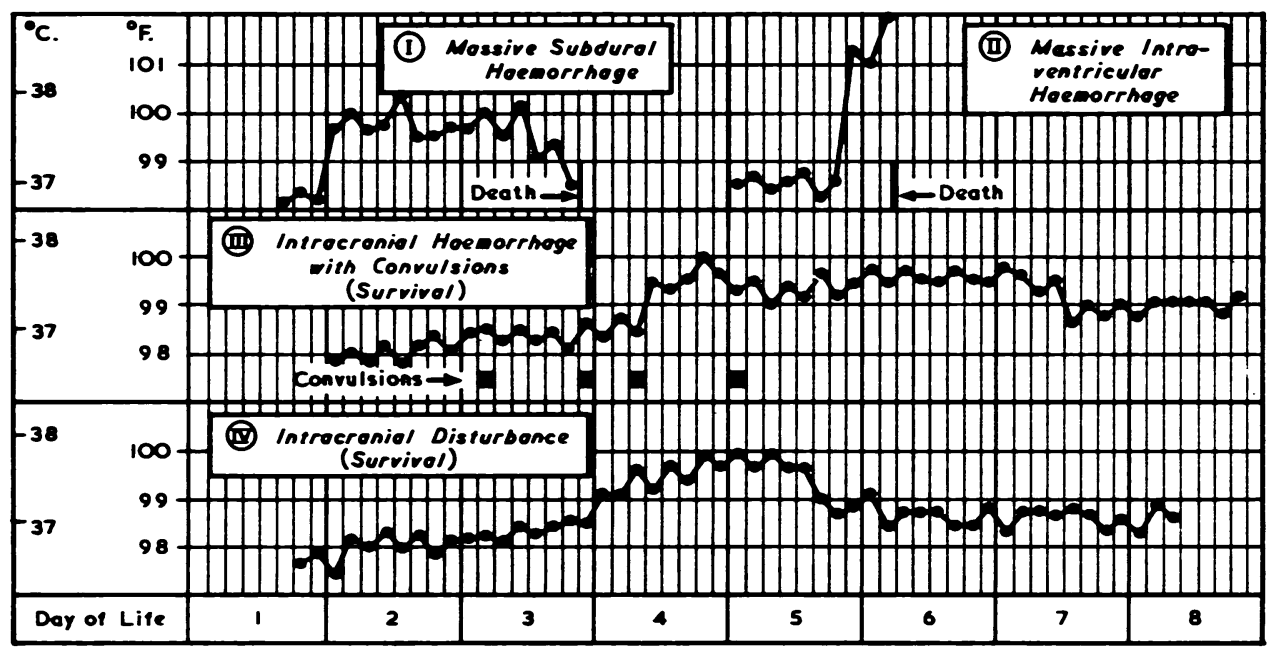

FiG. 3.-Pyrexia in association with stress of birth and or delivery (four examples). 


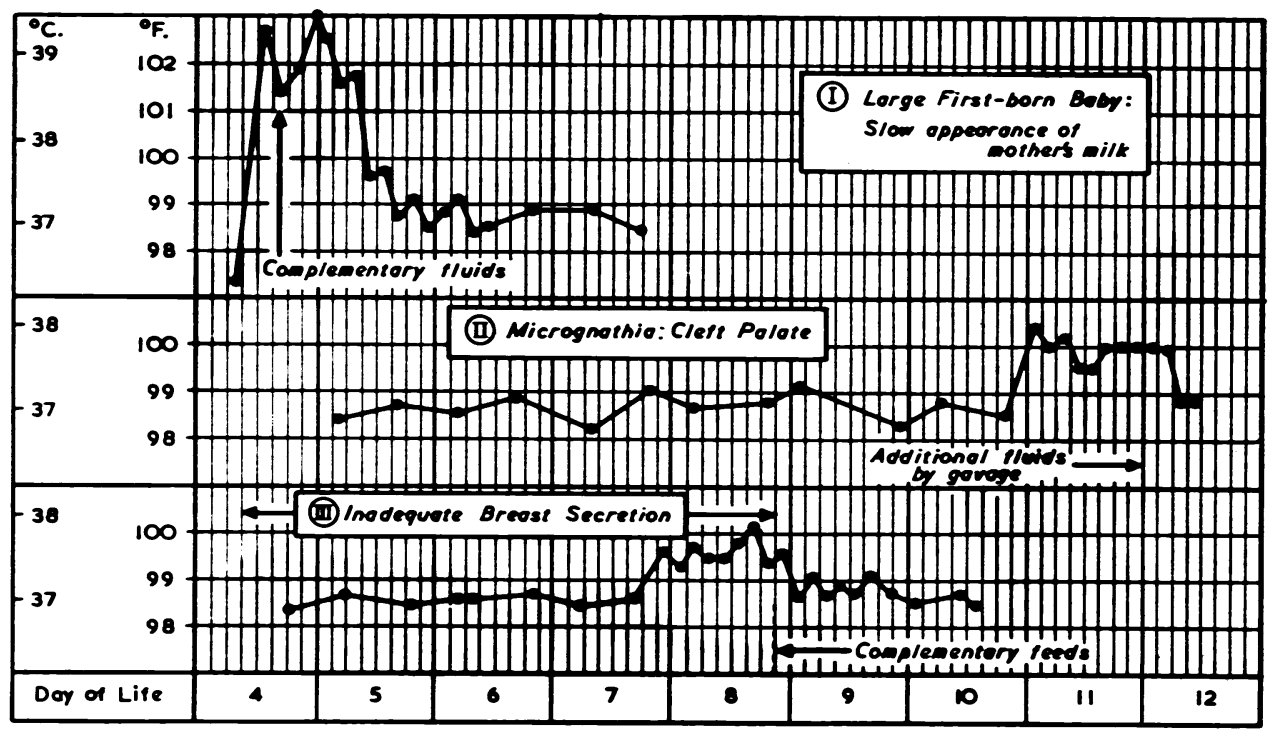

Fig. 4.-Pyrexia in association with inadequate fluid (three examples).

Pyrexia in the presence of intestinal haemorrhage settled quickly following effective spontaneous or therapeutic evacuation of the colon.

Congenital anomalies (Table 7): The nine babies with meningomyelocele were also hydrocephalic. As fluid intake was reasonable and there was no abnormal loss of fluid, the pyrexia may have been the result of disturbed central control. There was no evidence of infection or dehydration in the two babies with abnormalities of the urinary tract, but renal function was impaired in both. In all 11 babies the onset of pyrexia was early and the duration short. Otherwise there was no constant characteristic.

There were 10 notably active premature babies of birth weight not less than $5 \mathrm{lb} .4 \mathrm{oz}$. with moderate instability of temperature. The pyrexia never exceeded $102^{-}$F. $(38 \cdot 9:$ C.) and was intermittent over a period varying from two to 14 days. All the infants were healthy and in receipt of feeds appro-

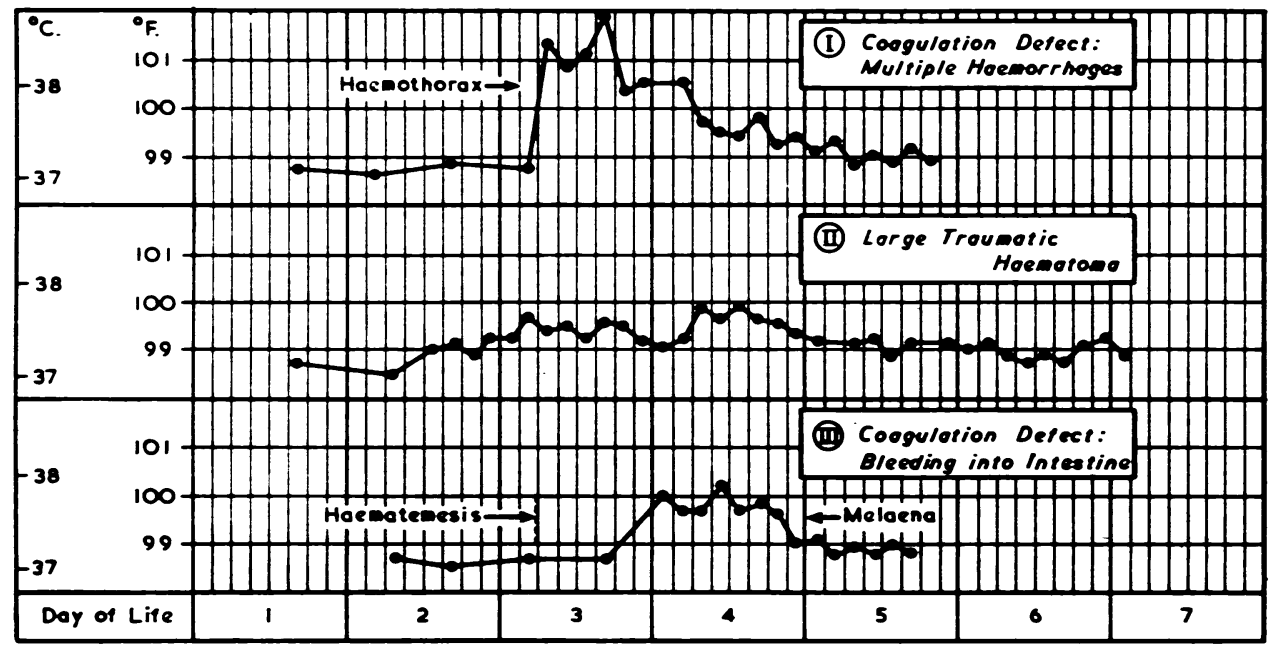

FKG. 5.-Pyrexia in association with retained blood (three examples). 
priate to their weight and maturity from the age of 36 hours.

Fever occurred in association with jaundice (Table 8) in nine babies. The time of onset of fever was related to the circumstances of the jaundice, being early in the presence of haemorrhagic disease and delayed in cases of bile-duct atresia and kernikterus. The temperature was continuous, intermittent or remittent in character, and exceeded $104^{\circ} \mathrm{F} .\left(40^{\circ} \mathrm{C}\right.$. $)$ in two cases of kernikterus.

\section{Incidence of Fever in Association with Certain Clinical Conditions}

All babies in the Maternity Hospital with clinical evidence of infection, severe perinatal distress or convulsions are admitted to the special baby care unit of the hospital. The total number of infants admitted with these conditions to the unit during the period of the study is given in column ii of Table 9. Column iii gives the number of babies in each clinical group who were found to be pyrexial. Fever was a feature of $68 \%$ of infants with deep and $50 \%$ of those with superficial infection. Forms of infection in which pyrexia was most commonly absent included those involving the upper respiratory tract, the intestines and the skin. Pyrexia was recorded in only $12 \%$ of babies under observation for perinatal stress. The incidence of fever was greater in those cases of postnatal intracranial disturbance, which developed convulsions.

In series B. 49 babies had convulsions. Of these babies, 17 were suffering from septicaemia and six from pyelonephritis, and in every instance fever preceded the occurrence of convulsions by an interval of one or more days. The sequence of events was the reverse in infants in whom there was evidence of postnatal intracranial distress and in whom both fever and convulsions were noted. Among 22 such infants a rise of temperature followed the development of convulsions in 20 after a varying interval of six to $\mathbf{4 8}$ hours. Fever and convulsions developed simultaneously in the other two infants. Convulsions preceded pyrexia in the remainder of the 49 babies, of whom one remained undiagnosed; one developed signs 36 hours after an exchange transfusion, and two as previously reported passed large massive undigested stools simultaneously with the occurrence of convulsions (Craig, 1960). In the six cases of tetany included in Series B, fever developed towards the end or immediately after incidents of prolonged violent neuromuscular hyperexcitability.

\section{Fatal Cases}

There were no deaths in Series A and 47 deaths
TABLE 7

PYREXIA ASSOCIATED WITH CONGENITAL ANOMALIES (11 INFANTS)

\begin{tabular}{|c|c|c|c|c|c|}
\hline \multicolumn{5}{|c|}{ Congenital Anomaly } & No. of Babies \\
\hline $\begin{array}{l}\text { C.N.S.: meningomyelocele } \\
\text { Encephalocele }\end{array}$ & $\begin{array}{l}\cdots \\
\cdots\end{array}$ & $\begin{array}{l}\cdots \\
\cdots\end{array}$ & $\begin{array}{l}\cdots \\
\cdots\end{array}$ & $\begin{array}{l}\cdots \\
\cdots\end{array}$ & i) 9 \\
\hline $\begin{array}{l}\text { Urinary: ectopic bladder } \\
\text { Cystic disease of kidneys }\end{array}$ & $\begin{array}{l}\cdots \\
\cdots\end{array}$ & $\begin{array}{l}\cdots \\
\cdots\end{array}$ & $\begin{array}{l}\cdots \\
\cdots\end{array}$ & $\begin{array}{l}\cdots \\
\cdots\end{array}$ & is 2 \\
\hline
\end{tabular}

TABLE 8

PYREXIA IN ASSOCIATION WITH JAUNDICE (NINE INFANTS)

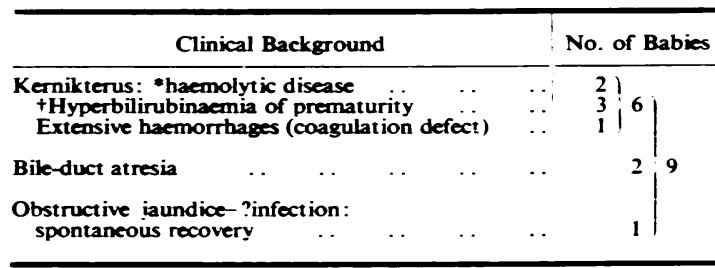

- Simple transfusions only

+ No transfusions.

TABLE 9

INCIDENCE OF RAISED TEMPERATURES IN CERTAIN SELECTED CLINICAL CONDITIONS

\begin{tabular}{|c|c|c|c|c|c|c|c|c|}
\hline \multirow{2}{*}{\multicolumn{3}{|c|}{$\begin{array}{c}\text { Clinical Group } \\
\text { (i) }\end{array}$}} & \multicolumn{4}{|c|}{ Number of Infants } & \multirow{2}{*}{\multicolumn{2}{|c|}{$\begin{array}{c}\text { With } \\
\text { Pyrexia } \\
\text { (iv) }\end{array}$}} \\
\hline & & & \multicolumn{2}{|c|}{$\begin{array}{c}\text { Total* } \\
\text { (ii) }\end{array}$} & \multicolumn{2}{|c|}{$\begin{array}{l}\text { With } \\
\text { Pyrexia } \\
\text { (iii) }\end{array}$} & & \\
\hline $\begin{array}{l}\text { Deep Infection: } \\
\text { Meningitis septicaem } \\
\text { Pneumonia-Staphyl } \\
\text { Other } \\
\text { Pyelonephritis . . } \\
\text { Gastro-enterit is } \\
\text { Osteomyelitis . . } \\
\text { Uprer respiratory }\end{array}$ & $\begin{array}{l}\text { ia } \\
\text { lococca! } \\
\ldots \\
\cdots \\
\cdots \\
\cdots\end{array}$ & $\begin{array}{l}\cdots \\
\cdots \\
\cdots \\
\cdots \\
\cdots\end{array}$ & \begin{tabular}{r|r}
27 \\
11 \\
12 \\
17 \\
24 \\
6 \\
21
\end{tabular} & 118 & \begin{tabular}{r|}
25 \\
11 \\
8 \\
17 \\
8 \\
6 \\
5
\end{tabular} & 80 & $\begin{array}{r}92 \\
100 \\
67 \\
100 \\
33 \\
100 \\
24\end{array}$ & 68 \\
\hline $\begin{array}{l}\text { Superficial Infection: } \\
\text { Skin (severe) } \quad \ldots \\
\text { Mastitis } \\
\text { Cellulitis } \\
\text { Salivary glands }\end{array}$ & $\begin{array}{l}\cdots \\
\cdots \\
\cdots\end{array}$ & $\begin{array}{l}\cdots \\
\cdots \\
\cdots\end{array}$ & $\begin{array}{r}43 \\
12 ! \\
6 \\
5\end{array}$ & 66 & $\left.\begin{array}{r|}14 \\
11 \\
6 \\
2\end{array}\right)$ & 33 & $\begin{array}{r}32 \\
93 \\
100 \\
40\end{array}$ & 50 \\
\hline Entero-colitis & . & . & & 39 & & 2 & & $\leq$ \\
\hline $\begin{array}{c}\text { Stress of Delivery birth } \\
\text { Asphyxia: } \\
\text { without convulsion } \\
\text { with convulsions } \\
\text { +Intracranial disturb } \\
\text { without convulsion } \\
\text { with convulsions } \\
\text { Intracranial haemorr } \\
\text { without convulsion } \\
\text { with convulsions }\end{array}$ & $\begin{array}{l}\text { is } \\
\text { ince: } \\
\text { hage: } \\
\text { is } \\
\text {. }\end{array}$ & $\begin{array}{l}\cdots \\
\cdots \\
\cdots \\
\cdots \\
\cdots\end{array}$ & $\begin{array}{r}461 \\
18 \\
167 \\
23 \\
63 \\
2\end{array} \mid$ & 734 & $\left.\begin{array}{r}36 \\
14 \\
20 \\
6 \\
8 \\
2\end{array}\right)$ & 86 & $\begin{array}{r}8 \\
78 \\
12 \\
26 \\
13 \\
100\end{array}$ & 12 \\
\hline $\begin{array}{c}\text { Convulsions in Other } \\
\text { stances: } \\
\text { Cerebral agenesis } \\
\text { Miscellaneous .. }\end{array}$ & $\begin{array}{l}\text { Circum- } \\
\ldots \\
\ldots\end{array}$ & $\begin{array}{l}\cdots \\
\cdots\end{array}$ & $\left.\begin{array}{r}12 \\
9\end{array}\right\}$ & 21 & $\left.\begin{array}{l}4 \\
4\end{array}\right\}$ & 8 & $\left.\begin{array}{l}33 \\
44\end{array}\right\}$ & 38 \\
\hline
\end{tabular}

- Includes only infants nursed in an open cot without an electric blanket or hot-water bottles.

+ Neuromuscular irritability following difficult delivery or birth irrespective of whether signs of asphyxia were present. 
in Series B. Death was attributable to deep infection in 19, congenital anomalies in 14 , intracranial haemorrhage in nine, haemolytic disease in three and duodenal haemorrhage in two babies. Pyrexia exceeded $102^{-} \mathrm{F} .\left(38^{\cdot} 9^{-} \mathrm{C}\right.$.) in 17 of the 19 cases of deep infection, being remittent or intermittent in each case. The highest and most irregular temperatures were encountered in infants with staphylococcal septicaemia, and the organism cultured from the blood in the two babies with maximum temperatures of less than $100^{\circ}$ F. $\left(37 \cdot 8^{-}\right.$C.) was Streptococcus viridans. Fever in babies dying with subdural haemorrhage as a result of tentorial tears did not exceed $101 \cdot 6^{*}$ F. $\left(38 \cdot 7^{\circ} \mathrm{C}\right)$, whereas temperatures ranging from $102=$ to $105^{*}$ F. $\left(38 \cdot 9^{=}\right.$$40 \cdot 5^{-}$C.) were recorded in infants with intraventricular haemorrhage. There was no characteristic pattern of pyrexia in infants in whom death was due to congenital anomalies, haemolytic disease or duodenal haemorrhage.

\section{Discussion}

Holt and McIntosh (1953a) consider that the temperature of infants should be taken in the rectum. The technique employed in obtaining rectal temperature recordings in the present study takes account of the recommendations of Moncrieff and Hussey (1948) and Karlberg (1949). There is agreement that the body temperature falls during the first few hours following birth and thereafter rises to a level of $98^{*}-99^{\circ}$ F. $\left(36 \cdot 7^{i}-37 \cdot 2^{\prime}\right.$ C. $)$ within eight to 12 hours (Paterson and McCreary, 1956; Myles, 1961; Sanford and Grulee, 1961a). von Reuss (1921) considers that a return to normal takes place about the second day of life. In the present study all observations are based on temperatures recorded after the first day of life.

Paterson and McCreary (1956), Myles (1961) and Sanford and Grulee (1961a) give a temperature of $98^{\circ}-99^{\circ}$ F. $\left(36 \cdot 7^{\circ}-37 \cdot 2^{\circ}\right.$ C. $)$ as normal after initial stabilization. Holt and McIntosh (1953a) are of the opinion that under normal conditions the range of rectal temperature is $98^{\circ}-99 \cdot 5^{\circ} \mathrm{F}$. $\left(36^{\cdot} \cdot 7^{\circ}-37 \cdot 5^{\circ} \mathrm{C}\right.$.). The findings in Series A of the present study support the view that a rectal body temperature in excess of $99^{=}$F. $(37 \cdot 2=$ C. $)$ is probably abnormal. To attach too precise or too arbitrary significance to an absolute temperature recording of $99^{\circ} \mathrm{F} .\left(37 \cdot 2^{-} \mathrm{C}\right.$.) would be erroneous. For the purpose of Series B, therefore, only temperature readings in excess of $99 \cdot 4^{\prime}$ F. $\left(37 \cdot 4^{\circ}\right.$ C. $)$ have been accepted as evidence of pyrexia. It is suggested by Dunham (1955) that the rectal temperature in premature babies may be lower than in babies born at term. This would not, however, appear to be a factor of importance in this study in view of the relatively small number of premature babies included in Series B and of the fact that none of them was of a gestation period less than 36 weeks. Pyrexia in the newborn baby may result from a too high environmental temperature (McKay and Smith, 1959a). The possibility that high incubator temperatures may explain an abnormal rise in body temperature is stressed by Lubchenco (1961), and for this reason babies nursed in incubators were not included in this study.

Infection. That infection can result in pyrexia is generally accepted. On the other hand most references to fever due to infection are qualified. Thus Parmelee (1948) is of the opinion that fever in these circumstances is rarely high and may be absent. Sanford and Grulee (1961b) state that the temperature may be subnormal in $50 \%$ of cases of septicaemia and that in the remainder a rise above $102^{\circ}$ F. $\left(38 \cdot 8^{\circ}\right.$ C.) is unusual. According to Schaffer (1960) a minority only of cases of neonatal sepsis are afebrile. Considering infection in general. Stone (1945) describes fever as a variable sign, there sometimes being extreme temperatures and at other times no febrile reaction. Findings in this study confirm the view of McKay and Smith (1959a) that, in the absence of dehydration and high environmental temperature, pneumonia, septicaemia and meningitis are among the commonest causes of temperatures over $100^{\circ} \mathrm{F} .\left(37 \cdot 8^{-} \mathrm{C}\right.$.); however, they: do not suggest that, in so far as babies born at term are concerned, a subnormal or normal temperature is a customary finding in these conditions. Contrary to the point made by Holt and McIntosh (1953b) and Stone (1945) that fever attributable to infection seldom develops before the fifth or sixth day, pyrexia was first noted within three days of birth in 14 of the infants with subsequent evidence of deep infection. By way of contrast, fever of early onset was altogether exceptional in babies developing superficial infection.

Dehydration. Inanition or dehydration fever in the newborn has for long been accepted as a clinical "entity". von Reuss (1921) refers to the condition as transitory fever which he describes as consisting usually of short periods of fever that may be remittent over a period of a few days. According to Stone (1945) dehydration fever is of intermittent or remittent type, coming and going rather suddenly in the first week, while McKay and Smith (1959b) refer to rises in temperature to $100^{\circ}-104^{\circ} \mathrm{F}$. (37.8 $40^{-}$C.) on the second or third day. Sanford and Grulee (1961a) suggest that increased concern with 
infection in the newborn explains the lessening interest of recent years in dehydration fever. They are, nevertheless, sceptical about the existence of the condition, and focus attention on the fluctuations to which body temperature in the newborn is subject.

In continuing to accept the view that dehydration fever is an entity, I have been influenced by certain general observations. Findings in control Series A indicate that increases in body temperature above $99^{\prime} \mathrm{F} .\left(37 \cdot 2^{\prime}\right.$ C. $)$ rarely occur in healthy newborn babies who are being nursed in a reasonable environmental temperature. The factors contributing to fluid lack in the babies with dehydration varied (Table 5), but with increase of fluids the subsequent clinical course of events was in keeping with recorded descriptions of inanition or dehydration fever. Furthermore, at one time it was my practice to offer fluids in minimal amounts for some days to babies with signs of severe postnatal intracranial distress. When the practice was discontinued there was an unmistakable decline in the incidence of pyrexial episodes in such babies. Another group of interest consisted of newborn babies with pylorospasm. Experience has shown that prompt gastric lavage results in a speedy lessening in the frequency and severity of vomiting (Craig, 1961). With the institution of gastric lavage as a routine temporary procedure, transient fever which used to be a not uncommon feature is now rarely encountered in these cases. A further point deserving emphasis is the infrequency with which fever occurs in association with entero-colitis that is not accompanied by vomiting (Table 9) in contrast with gastroenteritis in which loss of fluid is contributed to by both vomiting and diarrhoea. In so far as loss of fluid contributes to pyrexia, the figures in Table 5 suggest that vomiting is of major importance. One possibility that has to be considered is that in the main, interest in dehydration fever has been limited to those cases in which elevation of the body temperature has been considerable. Holt and McIntosh (1953c), for example, are of the opinion that a temperature of $101^{\circ} \mathrm{F}$. $\left(38 \cdot 3^{\circ} \mathrm{C}\right.$.) or more is an indication for additional fluids. Dunham (1955) points out that fever may be absent in the presence of dehydration. Findings in this study (Table 2) show that body temperatures of less than $100^{\circ} \mathrm{F}$. $\left(37 \cdot 8^{\circ} \mathrm{C}\right.$.) are rather more common than those above that level in this condition.

Perinatal Stress. In the series under consideration pyrexia was associated more frequently with perinatal stress than with dehydration, and was characterized by transient fever of $99.5^{\circ}$ to $102^{\circ} \mathrm{F}$.
$(37 \cdot 5-38 \cdot 9 \div$ C.) developing within two, three or at most four days after birth and only rarely persisting for more than two days. Birth stress complicated by convulsions was associated with an increased liability to fever. The most pronounced febrile reactions were found in cases with severe intracranial haemorrhage as demonstrated at autopsy or by lumbar puncture. Beeson (1952) remarks upon the frequent finding of faulty temperature regulation in babies with cerebral birth injury but does not discuss the pathogenesis of the fever. A broad analogy may be drawn with findings in head injury among older subjects. Thus a slight rise in temperature takes place in a proportion of newborn babies with minor intracranial disturbance and of older subjects with mild concussion; and a pronounced pyrexial reaction is more frequently encountered in the most severe forms of cerebral injury, whether arising from trauma at birth or later in life. A further point of resemblance is the high temperature present in many cases of neonatal ventricular haemorrhage and in older subjects with disease in the neighbourhood of the base of the brain.

It has been suggested (Menkin, 1945; Bennett, 1948) that fever may reflect the disturbance of central thermal control by breakdown products from damaged tissues. If the theory is correct it could well explain the temperatures in Series B, recorded in babies with intracranial disturbance, kernikterus, extensive haematoma and bleeding into serous cavities. Nor is it unreasonable to extend the explanation to temperatures occurring in infants in whom large amounts of blood were retained for prolonged periods in the alimentary tract. The argument is not invalidated by the fact that the blood in some of the infants in question was of maternal and not intrinsic origin. In the absence of a satisfactory alternative, a similar explanation may account for the otherwise unexplained fever which was noted to subside in five babies after the sudden expulsion of an unusually large and notably putrefactive isolated motion.

Although both fever and convulsions occurred in 49 of the babies in Series B, the findings are not contrary to the view previously expressed that in the early days of life febrile convulsions rarely occur in the absence of organic disease (Craig, 1960). With one exception the presence of an organic disorder was established in each case. In cases of intracranial birth stress, convulsions usually precede fever, suggesting that in such circumstances pyrexia is contributed to by, and is not the cause of the convulsions. It cannot, however, be said that convulsions provide the whole 
explanation of the fever because, as mentioned by Beeson (1952), disturbed temperature regulation is a not infrequent accompaniment of birth injury, and from Tables 4 and 9 it is evident that this applies in the absence of complicating convulsions.

Temperature Recordings as Aids to Diagnosis. Opinions concerning the value of temperature recordings have not hitherto been crystallized. The quotation (Sanford and Grulee, 1961a) heading this paper represents one view. Holt and McIntosh (1953b), on the other hand, categorically recommend that the temperature of the newborn should be taken at least twice daily. They (Holt and McIntosh, 1953b) refer to the variability of fever and leucocytosis, and to the fact that absence of fever does not exclude sepsis; and McKay and Smith (1959b), Parmelee (1948) and Stone (1945) emphasize that serious infection can exist in the absence of any febrile response. In so far as the premature infant is concerned Lubchenco (1961) considers that instability of temperature is a more reliable sign of infection than a low or a raised body temperature.

The fact that a raised rectal temperature was recorded in $68 \%$ of infants with deep infection (Table 9) is evidence that fever occurs with significant frequency in the presence of sepsis. For reasons already explained the series of 358 infants included only 77 premature babies, and observations therefore apply strictly to infants born at term or after. It can be stated, however, that a high percentage of premature babies with deep infections who were nursed in incubators and who were not included in Series B, did in fact have remittent or intermittent pyrexia.

Extensive pneumonia (other than staphylococcal) and widespread septicaemia were the types of deep infection in which hypothermia was most commonly observed. Regardless of maturity, temperature recordings had an unquestionable diagnostic value. This was especially true in cases of pyelonephritis, osteomyelitis, omphalitis and mastitis in which pyrexia was almost invariably the first abnormal clinical sign detected. The practical significance of this is illustrated by the development of severe infection within 36 hours of discharge home in three babies known to have had pyrexia during the two days preceding discharge (Fig. 1). Surprisingly, fever developed simultaneously with the first appearance of local signs of cellulitis. In cases of severe skin infection and furunculosis, a rise in temperature followed the appearance of other signs of infection after an interval of 36 to 48 hours. In general, pyrexias characterized by early onset were associated with a more pronounced absolute leucocytosis $(40,000$ to 60,000 per c.mm.) and a higher relative polymorph leucocytosis $(50-80 \%)$ than fevers that were detected after other evidence of manifest infection. Response of fever to additional fluids in the absence of infection or trauma serves as a useful form of therapeutic diagnostic confirmation in babies with dehydration.

Temperature Recordings as Aids to Immediate Prognosis. The presence or absence of fever in cases of intracranial distress is of little diagnostic value, but fever in such circumstances calls for caution in immediate prognosis as febrile cases of birth stress tended to run either more severe or rather more prolonged courses. Observations concerning the persistence of fever and in particular the persistence of remittent or intermittent pyrexial tendencies were invaluable in assessing response to treatment, and the necessity or otherwise for therapeutic adjustments in cases of septicaemia, osteomyelitis and meningitis. Lessening lability of the body temperature followed by stabilization at a progressively lower level were found to be favourable prognostic signs that were frequently recognizable before significant changes took place in the peripheral blood picture of babies with septicaemia and pyelonephritis. The disappearance of fever complicating intracranial birth injury was frequently one of the earliest signs of clinical improvement. Persistence of fever, more especially if accompanied by cyanosis and occasional vomiting was a feature of a proportion of babies dying as a result of massive intracranial haemorrhage.

Are Routine Temperature Recordings Necessary? The need to minimize demands on nursing staff make it obligatory to dispense with unwarranted routine measures. Can routine temperature recordings $0_{n}$ the newborn baby be dispensed with without detriment to the infant? It has been demonstrated that in the presence of disease significant rises in temperature probably occur with greater frequency than is sometimes supposed; that in a varicty of conditions temperature recordings have diagnostic and prognostic value; and that pyrexia is the most common first detectable sign in certain types of infection. These positive findings have to be evaluated in the light of the known risk of infection in maternity hospital nurseries and of the insufficiently appreciated risk of infection contracted in hospital not becoming manifest until after the baby"s discharge home. The case for routine temperature recordings on newborn babies in hospital is indisputable-quite apart from the need to detect 
hypothermia. Twice daily recordings are adequate, but these must be continued until the day of discharge. The temperature chart of a baby due for discharge should be studied particularly for any recent febrile event which may be a warning of an infection in process of incubation.

\section{Summary}

A rectal temperature in excess of $99 \cdot 4=F$. $\left(37 \cdot 4^{\circ}\right.$ C. $)$ is accepted as evidence of pyrexia in the newborn infant.

Two series were studied. Series A was a control series of 292 babies admitted to a lying-in ward over a period of 12 months, and Series $B$ was a major series of 358 babies who developed pyrexia while in the special baby care unit of the same hospital during a nine-year period. Forty-seven of the infants died. Babies in both series were nursed in open cots without hot-water bottles or electric blankets.

Pyrexia contributed to by dehydration or infection was recorded in 10 infants in the control series.

Pyrexia in the major series is reviewed in relation to age at onset, maximum elevation, duration, character and clinical background.

Infection, stress of labour and/or delivery and dehydration were the most common contributory factors of pyrexia in that order of frequency. Less common factors included retained blood, congenital anomalies, prematurity and jaundice.

Deep infections were associated with fever of later onset, greater severity and longer duration than superficial infections.

Pyrexia was a feature of $68 \%$ of infants with deep and $50 \%$ of infants with superficial infections.

Among babies with non-infective postnatal intracranial disturbance the incidence of fever was higher in those with convulsions.

Raised temperatures of less than $100^{\circ}$ F. $\left(37 \cdot 8^{\circ} \mathrm{C}\right.$. $)$ were more common than those above $100^{\circ} \mathrm{F}$. in the presence of dehydration.

The value of routine temperature recordings in relation to early diagnosis and immediate prognosis is stressed.

Facilities for the study were generously granted by the senior obstetrical staff of the Leeds Maternity Hospital. I am indebted to Miss M. Pattullo: Departmental Sister and Sister J. Webster for help on the wards, and to Drs. J. M. Littlewood, T. V. Jabbar, R. Beaver, and Miss $E$. M. Bond for assistance in keeping and analysing clinical records and in following up cases.

\section{REFERENCES}

Beeson. P. B. (1952). Signs and Symptoms, 2nd ed., ed. C. M. MacBryde. Do. 386-408. Stanles Press. London.

Bennett. I. L. (1948). Observations on the fever caused by bacterial pyrogens. I. A study of the relationshis between the fever caused by bacterial pyrogens and the fever accomxanying acute infections. II. A study of the relationshin between the fevers caused by bacterial pyrogens and by the intravenous iniection of the sterile exudate of acute inflammation. $J$. exp. Med. 88. 267 and 279.

Craig. W. S (1960). Convulsive movements occurring in the first 10 days of life. Arch. Dis. Childh., 35, 336.

(1961). Vomiting in the early days of life. ibid., 36, 451

Dunham. E. C. (1955). Premature Infants, 2nd ed., p. 111 . Cassell. London.

Holt. L. E. and McIntosh. R. (1953a). Pediatrics, 12th ed.. p. 54. Appleton-Century-Crofts. New York.

Appleton-Century-Crofts. New

Karlberg. P. (1949). The significance of depth of insertion of the thermometer for recording rectal temperatures. Acta paediat. thermometer for rece
(Cppsala), 38, 359.

Lubchenco, L. O. (1961). Watching the newborn for disease. Pediat. Clin. N. Amer..8. 476.

McKay. R. J. and Smith. C. A. (1959a). In Textbook of Pediatrics. 7 th ed.. ed. W. E. Nelson. D. 315. Saunders, London.

Menkin, V. (1945). Chemical basis of fever with inflammation. Arch. Path. 39. 28.

Moncrieff. A. and Hussey. B. 1. (1948). Temperature recording in sick children. Brit. med. J.. 2.972.

Myles. M. F. (1961). Textbook for Midwives, p. 505. Livingstone,

Edinburgh.
Parmelee. A. H. (1948). In The Child in Health and Disease, ed. C. G. Grulee. D. 136. Williams and Wilkins, Baltimore.

Paterson. D. and McCreary. J. F. (1956). Pediatrics, p. 38. Lippincott. Philadelrhia.

von Reuss. A. R. (1921). The Diseases of the Newborn. John Bale. Sons and Danielsson, London.

Sanford. H. N. and Grulee, C. G. (1961a). In Brennemann's Practice of Pediarrics. ed. V. C. Kelley, vol. I, chap. 42, pp. 15 and 87

Schafer (1961b). ibid., p. 72.

Schaffer, A. J. (1960). Diseases of the Newborn, p. 680 . Saunders. London.

Stone. E. L. (1945). The New Born Infant. 3rd ed.. p. 53. Kimpton. London. 